\title{
Bailando, me paso el día bailando y los vecinos mientras tanto no paran de molestar. Parar de + INF as an Interruptive Verbal Periphrasis in Spanish
}

\author{
Mar Garachana
}

Citation: Garachana, Mar. 2021.

Bailando, me paso el día bailando y

los vecinos mientras tanto no paran de

molestar. Parar de + INF as an

Interruptive Verbal Periphrasis in

Spanish. Languages 6: 171. https://

doi.org/10.3390/languages6040171

Academic Editors: Renata Enghels, Fien De Latte and Linde Roels

Received: 1 July 2021

Accepted: 12 October 2021

Published: 18 October 2021

Publisher's Note: MDPI stays neutral with regard to jurisdictional claims in published maps and institutional affiliations.

Copyright: (C) 2021 by the author. Licensee MDPI, Basel, Switzerland. This article is an open access article distributed under the terms and conditions of the Creative Commons Attribution (CC BY) license (https:/ / creativecommons.org/licenses/by/ $4.0 /)$.
Department of Hispanic Studies, Literary Theory and Communication, Faculty of Philology and Communication, Gran Via de les Corts Catalanes, 585, 08018 Barcelona, Spain; margarachana@ub.edu

\begin{abstract}
The main aim of this paper is to describe the Spanish construction parar de + INF, an aspectual verbal periphrasis which expresses the interruption of the event referred to by the infinitive in affirmative clauses, and the continuity and repetition of this event in negative clauses. Parar de + INF is a verbal periphrasis whose consolidation in Spanish occurred in the twentieth and twenty-first centuries. The study on this structure is therefore associated with recent linguistic changes. Parar $d e+$ INF is a verbal periphrasis characteristic of the colloquial language, which has complicated the study of the real use of parar de + INF. The language used in situations of communicative proximity is under-represented in the corpora. Thus, estimates of the frequencies of use of linguistic forms associated with colloquial language forms should be taken with caution, as frequency of use may differ significantly across discourse traditions. In this regard, it is important to think about the role of frequency data in historical studies of language.
\end{abstract}

Keywords: verbal periphrases; superlexical verbs; interruptive aspect; Spanish; construction grammar

\section{Introduction}

The main aim of this paper is to describe the Spanish construction parar de + INF, an aspectual verbal periphrasis which expresses the interruption of the event referred to by the infinitive. Thus, the dinner referred to in (1) has been interrupted. No reference is made to whether the event expressed by the infinitive cenar was concluded, just that it stopped. This is also seen in (2) in relation to the event expressed by the verb llorar. That is, in contrast to verbal periphrases such as acabar de + INF or terminar de + INF (finish + INF), parar de + INF does not express the natural conclusion of the action expressed by the infinitive. Moreover, it is precisely this difference that can be observed between (1) and (2) and the examples in (3) and (4). In (3), the dinner has ended, whereas in (1) it has stopped. Furthermore, the strangeness of sentence (4) is due to the fact that we cannot attribute a reachable endpoint (telos) to llorar 'to cry'; it is not an action associated with a natural conclusion. In fact, the construction used in (5) appears in situations where the crying is not considered worthy of compassion, but is thought by the speaker to be an intentional action that is inappropriate or bothersome. Acabar de + INF can also express something that happened in the recent past, for instance in El niño acaba de llegar 'The boy just now arrived'.

(1) Paró de cenar porque se le hacía tarde para ir al teatro.

'He/she stopped having dinner because he/she would be late for the theatre.'

(2) Por fin ha parado de llorar. 'He/she has finally stopped crying.'

(3) Acabó de cenar a tiempo para ir al teatro.

'He/she ended her dinner in time to go to the theatre.'

(4) ?Ahora ha acabado de llorar.

'He/she has just now ended his/her crying.'

(5) ¿Qué? ¿Ya has acabado de llorar?

'What? Have you stopped crying yet?' 
Parar de + INF is a verbal periphrasis whose consolidation in Spanish occurred in the twentieth and twenty-first centuries. The study on this structure is therefore associated with recent linguistic changes. The aim of this paper is precisely that: to analyse the use of this verbal periphrasis in contemporary Spanish. For this analysis we have performed an exhaustive search of the Spanish CORDE and CORPES XXI corpora. Further analysis covered the use of parar de + INF between 1975 and 2000, for which the Spanish CREA corpus was consulted. Twitter was also consulted to find examples of the construction parar de + INF. All of this furnished us with a total of 3955 examples from the twenty-first century and 324 from the thirteenth century to the end of the twentieth century. Methodologically, we adopt a usage-based approach to language change, and we follow the theoretical principles of construction grammar.

This paper is organised as follows. After this introduction (Section 1), we will provide a brief summary of the contributions made in the field to date, providing a general description of the characteristics of the construction under study (Section 2). The third section offers a brief description of the evolution of parar de + INF over time and a discussion on the impact of oral language on the language change, and, in particular, on how historical linguists trace these processes on the basis of data obtained from written texts. In the fourth section, the use of parar de + INF in contemporary language will be described. Finally, the fifth section will set forth some conclusions obtained from this study.

\section{What Do We Know about the parar de + INF Construction?}

The relatively recent appearance of this verbal periphrasis (cf. Section 3 ) is what has motivated the scarce attention paid to it in the literature. Interest in interruptive verbal periphrases has customarily focused on the quasi-synonymous construction of dejar de + INF, which boasts a longer trajectory in the Spanish language. If to this we add the fact that parar de + INF has not yet been fully consolidated in a number of usage contexts, it is not surprising that, for some scholars, it is still not considered a verbal periphrasis. Thus, parar de + INF is not included in the work of Gómez Manzano (1992), Gómez Torrego (1988), or Morera (1991). However, it does appear in the studies conducted by Olbertz (1998), Gómez Torrego (1999), Camus Bergareche (2006), and in NGLE (2009) as well as in Aparicio Mera (2016). All of these authors stress that parar de + INF is a rarely used construction in Spanish.

For Olbertz (1998, p. 92), the verb parar in this verbal periphrasis functions as a semiauxiliary verb, which she identifies as a verb of aspect, following García (1967). According to Olbertz (1998, p. 93) parar belongs to the "inner aspect" category, which, in contrast to that of the "outer aspect", affects the state of affairs expressed by the infinitive, so that it favours the presence of certain verbs in this position. In the case of parar de + INF, the egressive aspect attributed to it by Olbertz means that in the position of the auxiliated verb we will see infinitives whose meanings are associated with dynamic predicates, and, then, parar de + INF expresses telic events.

According to Olbertz (1998, p. 109), there is a dialectal difference that would make the use of parar de + INF in affirmative contexts nearly impossible in European Spanish, where it appears almost exclusively in the negative (however, see Section 4 containing the results of our corpus work). Furthermore, Olbertz indicates that parar de + INF does not impose any restrictions on the subject, which can be inanimate (6). Moreover, pronominalisation is not feasible (7). Still, for this author, that this construction can be used without the infinitive verb (El tronco en la chimenea arde y no para; 'The log in the chimney burns and does not stop') means that parar de + INF does not function as a verbal periphrasis. Olbertz follows the general idea that verbal periphrases cannot appear without their non-finite verb, as, in this case, the auxiliary verb will function as a main verb. Nevertheless, Olbertz maintains that the semi-auxiliary use of parar cannot be identified with the meaning it conveys as a full lexical verb, which expresses the interruption of a movement. She admits that there are two differentiated forms of the verb parar, one that is intransitive, and one that acts as a semi-auxiliary. 
(6) El tronco en la chimenea no para de arder. (Olbertz 1998, p. 110)

'The $\log$ in the fireplace does not stop burning.'

(7) *Le hacían tantos encargos que parecía que nunca iban a parar de eso. (Olbertz 1998, p. 111)

'They commissioned so many works that it seemed as though they would never stop doing so.'

Other authors who have studied parar de + INF consider it to be a verbal periphrasis, although a few, such as Fernández de Castro (1999), are uncertain in this regard. This author includes parar de + INF in a classification table of verbal periphrases (cf. Fernández de Castro 1999, pp. 148, 337), and even states that, when used in negative constructions, this form functions as a full periphrastic structure (Fernández de Castro 1999, p. 267). However, in the same book, Fernández de Castro also asserts that parar de + INF also functions as a verb governing a 'supplement', to quote the term used by the author (Fernández de Castro 1999, p. 73). ${ }^{1}$ Gómez Torrego (1999, p. 3382) is more decisive as he maintains that parar de INF is a verbal periphrasis, as it does not restrict the type of subjects of the construction. Moreover, nominalisations are not possible (see example 7 above). Even so, the author accepts the restrictions indicated by Olbertz for this construction, namely, the possible omission of the infinitive and the restrictions on the kind of verb that can be used with parar. Furthermore, Gómez Torrego notes that parar de + INF is most frequently found in the negative, and that it does not accept the passive.

Camus Bergareche (2006, p. 206) stresses the periphrastic nature of parar de + INF, insisting on the criteria previously indicated by Olbertz (1998) and Gómez Torrego (1999). He indicates that in parar de + INF, the infinitive cannot be substituted by a pronoun, a noun, or a clause, and that the infinitive determines the selection of the arguments. In addition, he indicates that the infinitive cannot be focalised in an emphatic relative structure ( ${ }^{*} \mathrm{Hacia}$ los del salón, que de bailar es de lo que han parado; 'Towards those in the living-room, that dancing is what they have stopped', Camus Bergareche 2006, s.v. parar de + inf, p. 206). Moreover, clitic climbing is possible (no paraba de moverse-no se paraba de mover; 'he/she doesn't stop moving'). Contrary to Gómez Torrego (1999), for Camus Bergareche, the passivisation of the construction is possible (Fracasó en su intento de poner orden para que la ayuda humanitaria parara de ser enviada allí donde no hacía falta; 'She failed in her attempt to restore order so that humanitarian aid would stop being sent where it was not needed'). Moreover, and contrary to Olbertz and Gómez Torrego, omission of the infinitive does not invalidate the consideration of parar de + INF as a verbal periphrasis; it is simply a form of elision that is possible when the information expressed by the infinitive can be gathered from the context. These considerations allow us to uphold our position regarding the periphrastic nature of parar de + INF, which is, in our opinion, unquestionable.

Camus Bergareche (2006) also looks at the differences detected between parar de + INF and its quasi-synonym, dejar de + INF ('give up'/'abandon' /'let up' + INF). In his opinion, there are three characteristics that differentiate them. Firstly, the use of parar de + INF:

se usa preferentemente cuando se quiere transmitir la idea de que el evento verbal no va a volver a reanudarse. Por el contrario, cuando puede haber alguna posibilidad de que el evento prosiga más adelante, la perífrasis que suele elegirse es $<$ dejar de + INF $>$. (Camus Bergareche 2006, p. 207)

'is preferred when wishing to convey the idea that the verbal event will not resume. In contrast, when the possibility exists that the event will continue sometime in the future, the choice of verbal periphrasis tends to be $<$ dejar de + INF $>$.'

Thus, the difference between (8) and (9) has to do with the fact that (8) would be employed only to refer to what the snowploughs did on a particular day. In contrast, statement (9) would refer to the activity of these machines throughout the entire winter. The second difference cited by Camus Bergareche is that dejar de + INF is used for both expressing the interruption of actions under the control of the subject and actions whose interruption is unintentional. In contrast, parar de + INF is, for Camus Bergareche, a verbal 
periphrasis better suited to instances of non-volitional interruption, which favour its use with inanimate subjects or animate subjects who have no control over the event expressed by the infinitive. In his opinion, a statement such as ¿Cuándo pararás de fumar? ('When will you stop smoking?') is almost ungrammatical (see, however, Sections 4.1 and 4.3). The third and last difference between parar de + INF and dejar de + INF stems from the fact that only the second expression, as it is negated, may develop attenuative characteristics (No dejes de escribirme = escribeme; 'Don't stop writing to me $=$ write to me, please'). On the contrary, ?No pares de escribirme ('Don't stop writing to $\mathrm{me}^{\prime}$ ) is a non-acceptable sentence in Spanish).

(8) Cuando dejaba de nevar, salían las máquinas quitanieves.

'When it stopped snowing, the snowploughs came out.'

(9) Cuando paraba de nevar, salían las máquinas quitanieves.

'When it stopped snowing, the snowploughs would come out.'

To these differences, Aparicio Mera (2016) adds another one. This author analyses these verbal periphrases from the perspective of force dynamics and concludes that the precise energy needed to interrupt the event denoted by the infinitive is greater in parar $d e+$ INF than in dejar de + INF. ${ }^{2}$ The idea of a stronger energy connected to parar de + INF calls into question the statement by Camus Bergareche that parar de + INF is connected to a non-controlled reading. However, it is precisely this greater force that is needed to interrupt the event expressed by the infinitive which, for Aparicio Mera (2016), would explain the greater restrictions on the use of the verbal periphrasis using parar. In the opinion of this author, this would also explain why, in contrast to dejar de + INF, parar de + INF is construed using verbs expressing dynamic, atelic, and durative events (Aparicio Mera 2016, p. 286). Additionally, while dejar de + INF is linked to duration and atelicity, parar de + INF is connected with dynamic events. In the words of this author:

Si bien $<$ dejar de $+\mathrm{V}_{\text {Infinitivo }}>$, al igual que $<$ parar/cesar de $+\mathrm{V}_{\text {Infinitivo }}>$, denota el abandono (interrupción) del CAMINO antes de llegar a la meta, creemos que las perífrasis <parar/cesar de $+\mathrm{V}_{\text {Infinitivo }}>$ añaden algún matiz a la manera en cómo se lleva a cabo dicha interrupción: en este caso, el empleo de una DINÁMICA DE FUERZA (DF) más intensa que la que se utiliza en la perífrasis <dejar de + $\mathrm{V}_{\text {Infinitivo }}>$. (Aparicio Mera 2016, p. 286)

'Although $<$ dejar de $+\mathrm{V}_{\text {Infinitive }}>$, like $<$ parar/cesar de $+\mathrm{V}_{\text {Infinitive }}>$, denotes the act of leaving (interrupting) the PATH before arriving at the goal, we believe that the verbal periphrases $<$ parar/cesar de $+\mathrm{V}_{\text {Infinitive }}>$ add a further nuance in meaning as to the way in which said interruption has been effectuated: in this case, the use of a FORCE DYNAMIC (FD) that is greater than that used in the verbal periphrases $<$ dejar de $+\mathrm{V}_{\text {Infinitive }}>$.'

\section{Parar de + INF, a Verbal Periphrasis of Contemporary Language}

Parar de + INF is a relatively recent verbal periphrasis in the Spanish language. It originates from the constructionalisation of a form combining the verb parar ('to stop') and an infinitive. The lexical meaning of parar refers to the idea of interrupting a movement, and in the construction parar de + INF, the auxiliary verb parar retains the meaning of cessation, but only metaphorically: it is not a physical motion that is interrupted but an event expressed by the infinitive.

Even if tokens of parar de + INF date back to the Middle Ages, they are quite infrequent in the corpora before the twentieth century. As can be seen in Figure 1, the use of this verbal periphrasis peaked in the twenty-first century: only in the first two decades of this century did its normalised frequency of use exceed 10 occurrences per million words. The rise is especially notorious between 2016 and 2020, when parar de + INF reaches 19.31 occurrences per million words (for a more detailed explanation of the change over time of parar de + INF, cf. Garachana n.d.). 


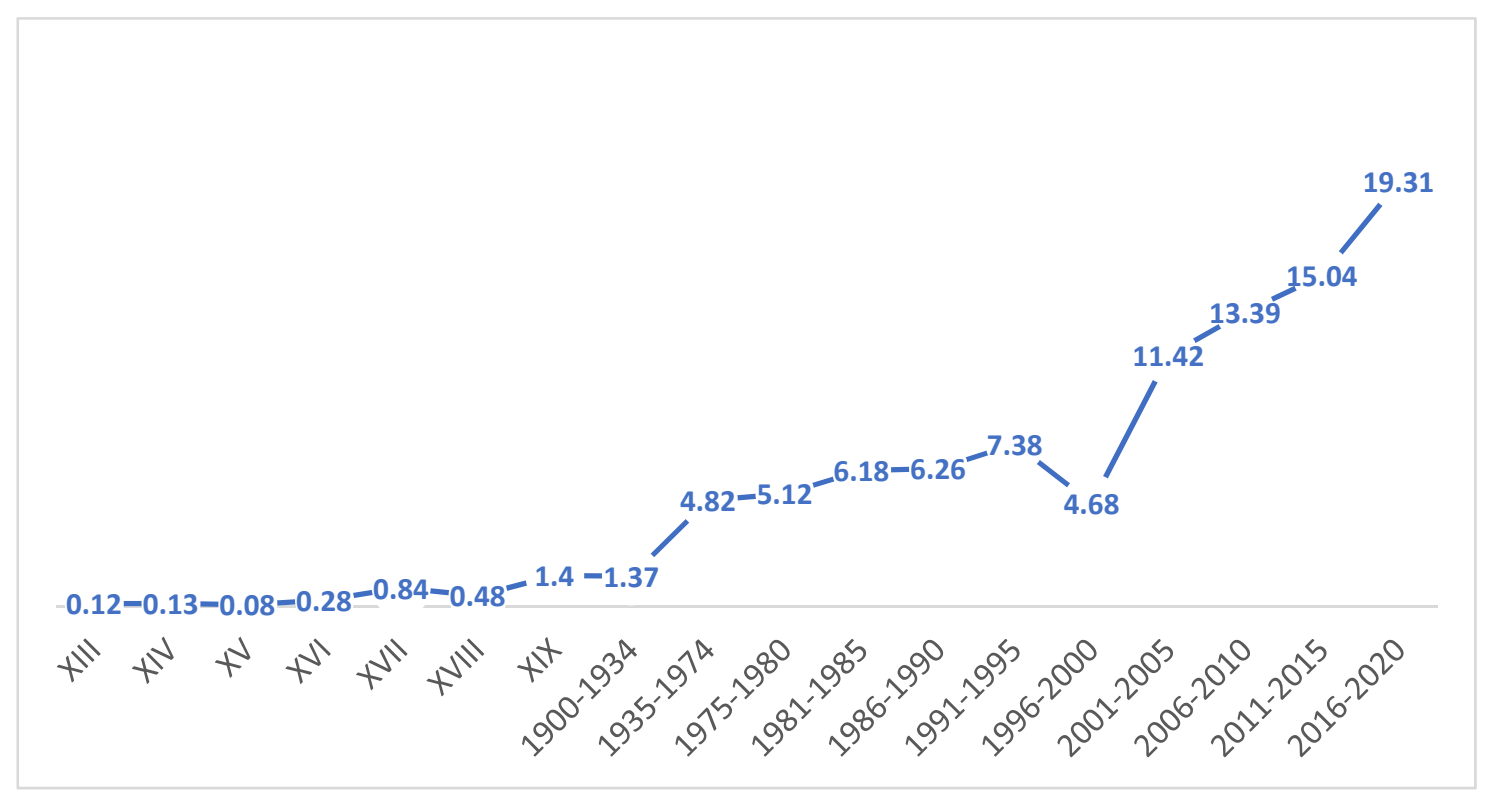

Figure 1. Frequency of use of parar de + INF in Spanish over time.

The verbal periphrasis parar de + INF is well established in contemporary language, and its frequency of use enables us to elaborate on previous descriptions of the construction, which maintained that it was a rarely used expression in Spanish. Indeed, its use is lower than that of its synonym dejar de + INF (if we look at its absolute frequencies in the twenty-first century, the results show 76,280 examples of dejar de + inf, compared with 3955 instances of parar de + inf), but it is quite possible that the large difference between these constructions is related to the contexts in which each is used. Compared to the more neutral dejar de + INF, parar de + INF appears in personal exchanges of marked expressivity, such as those exemplified below, where dejar de + INF and parar de + INF can alternate in some contexts. This can be seen in (10), which is a dialogue between a couple in love. Parar de + INF can also be used to formulate humorous complaints such as that seen in (11), complaints which are not directed to anyone in particular, but to a generic recipient (12), or expressions of joy, such as in (13).

(10) Daylica

Ya deja de ser tan lindo conmigo.

'Come on stop being so nice to me.'

Aldrich

Cuando tú pares de serlo conmigo. Te quiero puerquita. (Twitter, 14 September 2020) '[only] when you stop [being nice] to me. I love you my little piglet.'

(11) porfa puede Shein parar de enamorarme de todos los vestidos que tiene. (Twitter, 27 April 2021, 11:53 p.m.)

'please Shein stop making me fall in love with all the dresses you have.'

(12) "Tourist, go home", "Gaudí hates you" or "Parad de destrozar nuestras vidas" 'Stop ruining our lives'.

Estos son algunos de los mensajes que se encuentran muchos visitantes extranjeros pintados en las fachadas de algunos barrios de Barcelona, en España. ("El turismo no es bueno en todos lados". Available online: http:/ / castillosenlinea.blogspot.com/2017 /06/el-turismo-no-es-bueno-en-todos.html (accessed on 8 May 2021))

'These are some of the messages that have been painted on house fronts in some districts of Barcelona, Spain, directed to foreign visitors.'

(13) rrrosalía @nidepuntillas 
no puedo parar de ser una persona súper feliz en sant jordi. (Twitter, 23 April 2021)

'I can't stop feeling so happy on San Jordi.'

The informal character of this construction is observed in the types of texts in which it appears, that is, mainly narrative and dialogues. It is also frequently found in fragments in which the speaker is seeking greater expressive effect, or passages written in direct speech where priority is given to communicative proximity and where the periphrastic structure is employed in order to appeal to the interlocutor. ${ }^{3}$ Thus, its use in academic language, critical texts, newspaper columns, or opinion pieces is limited. Although it cannot be affirmed that parar de + INF is not used in formal texts, its particular expressive force makes it quite suitable in uses associated with the formulation of complaints, orders or wishes, or with the expression of counter-expectation.

Indeed, this is what has complicated the study of the real use of parar de + INF. The language used in situations of communicative proximity is under-represented in corpora. Thus, estimates of the frequencies of use of linguistic forms associated with colloquial language forms should be taken with caution, as frequency of use may differ significantly across discourse traditions (Cornillie et al. 2021; Kabatek 2013). In this regard, it is important to think about the role of frequency data in historical studies of language. Although other verbal periphrases may show greater use than parar de + INF, its very nature-that of a construction preferentially used in situations of communicative proximity-makes it especially suited for use in spoken language, which means it has a low presence in corpora.

Fortunately, social media platforms, such as Twitter, Facebook, and other technologically mediated means of communication, have undoubtedly favoured the expansion of forms of writing that permit elements typical of oral speech. The expansion of parar $d e+$ INF may also have been favoured by socio-linguistic trends that fostered the use of forms typically employed in situations of communicative proximity in its strictest sense in contexts that were traditionally reserved for more formal language use. Indeed, since the last third of the twentieth century, formal registers in Spanish have seen an increasing influx of colloquial forms. This phenomenon is particularly evident in Spain after the end of the Francoist dictatorship.

The sense linked to communicative proximity which impregnates many of the uses of parar de + INF, along with the expressivity that conditions many of the instances in which it occurs, hinders the study of this construction. As mentioned in the section above, this verbal periphrasis has not often awakened the interest of linguists. Moreover, its marked character makes it difficult to collect samples that permit a systematic study of its usage. Thus, although it is acknowledged that parar de + INF expresses meanings associated with interruptive and continuative uses, these are usually considered to be variants of a single construction. Yet it is our opinion that there are actually two different verbal periphrases, each with its own differentiated meaning: an interruptive one and a continuative one. The next section will provide further analysis of these considerations.

\section{Parar de + INF in the Perspective of Construction Grammar}

Parar de + INF has been described as an interruptive verbal periphrasis. Parar de + INF conveys aspectual meaning, and is a verbal periphrasis of lexical aspect (Olbertz 1998; Bravo Martín and García Fernández 2016; Havu 2011; Laca 2002), as forms of this kind are used to "inherently [denote] phases belonging to actions referred to by the verbs that accompany them" (Bravo Martín and García Fernández 2016, p. 793). This characteristic is largely due to the meaning of the auxiliary verb, which is considered to be a special type of auxiliary in the relevant literature. Here it is usually called a superlexical verb (Smith 1991, p. 48) or an aspectualiser verb characterised, precisely, for marking the phase of the event denoted by the infinitive. In contrast to periphrases of grammatical aspect, which offer information about the internal progress of the event expressed by the infinitive, periphrases of lexical aspect indicate the phase of the event (beginning, in progress, ending or interruption). This class of aspectual verbal periphrases includes empezar/comenzar $a+\mathrm{INF}$, entrar $a+\mathrm{INF}$, seguir + GER, dejar de + INF, parar de + INF, terminar/acabar de + INF, volver a + INF, and other 
forms (for an exhaustive list, cf. García Fernández 2006, p. 302). The superlexical verb is the element which confers the phase meaning to the construction, and therefore its status as a verbal periphrasis is sometimes called into question.

Nevertheless, it is particularly interesting to view constructions such as parar de + INF, empezar $a+$ INF or acabar de + INF as grammatical constructions conventionalised in the language, which link a particular form to a given meaning. ${ }^{4}$ This meaning is procedural, as the form gives us an instruction on how to interpret the phase of the event conveyed by the infinitive. In the case of the verb parar, the situation is somewhat different, since in its use as a lexical verb actually does have a full semantic value which expresses the interruption of a movement. In fact, even authors such as Olbertz (1998), who reject the classification of parar de INF as a verbal periphrasis, admit that parar, when used as an auxiliary, does not have the same meaning as the one evinced in its uses as a lexical verb (cf. Section 2). At any rate, in the verbal periphrasis, as in the lexical uses of the verb, parar expresses interruption. As a lexical verb, parar signals that the subject is obliged to stop. In the verbal periphrasis, the construction containing the verb parar cancels the natural conclusion of the event expressed by the infinitive, which is stopped.

Now, as indicated by the aforementioned literature on Spanish verbal periphrases, a relevant piece of information needs to be included in the description of this construction, namely, its use in mostly negative contexts. Indeed, in the twenty-first century, the use of parar de + INF in negative contexts is much higher than in affirmative statements. If we look at Table 1 , we can see that $92.48 \%$ of the instances of parar de + INF are associated with contexts in which the verbal periphrasis falls within the scope of a negative marker. This percentage is maintained, with slight variations, across the entire range of Spanishspeaking territories. Figures lower than $85 \%$ for use in negative contexts can only be found in Costa Rica, the United States, Guatemala, Puerto Rico, and especially Nicaragua, where affirmative contexts total $34.48 \%$. The clear propensity towards its use in negative contexts invalidates Olbertz's statement (1998, p. 109) which ascribes its uses in negative contexts to peninsular Spain, where its use in affirmative contexts would be practically unknown.

Table 1. Distribution of verbal periphrasis parar de + INF use by country.

\begin{tabular}{|c|c|c|}
\hline \multirow{2}{*}{ Country } & \multicolumn{2}{|c|}{ Percentage } \\
\hline & Affirmative & Negative \\
\hline Argentina & (38/386) 9.8\% & (348/386) 90.15\% \\
\hline Bolivia & $(3 / 52) 5.76 \%$ & $(49 / 52) 94.23 \%$ \\
\hline Chile & (19/176) $10.79 \%$ & (159/176) 89.20\% \\
\hline Colombia & (39/314) $12.42 \%$ & (275/314) 87.57\% \\
\hline Costa Rica & $(6 / 23) 26.08 \%$ & $(17 / 23) 73.91 \%$ \\
\hline Cuba & $(7 / 84) 8.33 \%$ & (77/84 $91.66 \%$ \\
\hline Ecuador & $(5 / 76) 6.57 \%$ & (71/76) $93.42 \%$ \\
\hline El Salvador & (1/36) $2.77 \%$ & $(35 / 36) 97.22 \%$ \\
\hline Spain & $(89 / 1936) 4.59 \%$ & (1847/1936 95.40\% \\
\hline USA & $(4 / 20) 20 \%$ & $(16 / 20) 80 \%$ \\
\hline Guatemala & $(6 / 36) 16.66 \%$ & (30/36) $83.33 \%$ \\
\hline Equatorial Guinea & $(1 / 21) 4.76 \%$ & (20/21) 95.23\% \\
\hline Honduras & $(6 / 48) 12.5 \%$ & $(42 / 48) 87.5 \%$ \\
\hline Mexico & (23/253) $9.09 \%$ & (230/253) $90.9 \%$ \\
\hline Nicaragua & (11/31) $35.48 \%$ & $(20 / 31) 64.51 \%$ \\
\hline Panama & $(0 / 11) 0 \%$ & $(11 / 11) 100 \%$ \\
\hline Paraguay & (7/49) $14.28 \%$ & $(42 / 49) 85.71 \%$ \\
\hline Peru & (4/104) 3.84\% & $(100 / 104) 96.15 \%$ \\
\hline Puerto Rico & $(5 / 35) 14.28 \%$ & $(30 / 35) 85.71 \%$ \\
\hline Dominican Republic & (4/38) $10.52 \%$ & (34/38) $89.47 \%$ \\
\hline Uruguay & $(7 / 85) 8.23 \%$ & (78/85) $91.76 \%$ \\
\hline Venezuela & (10/110) 9.09\% & (100/110) 90.90\% \\
\hline Total & (295/3924) $7.51 \%$ & (3629/3924) 92.48\% \\
\hline
\end{tabular}


As a result, the most frequent description of parar de + INF as a terminative aspectual verbal periphrasis can only be applicable to a small proportion of examples. If we broaden our study to include the negative construction where parar de + INF normally appears, we observe that a constructionist approach to the periphrastic verbs affords a description that better suits the way they are actually used in language.

The affinity of parar de + INF for negative contexts enables us to demarcate two perfectly separate constructions, as can be seen in Figure 2. On the one hand, we have an interruptive verbal periphrasis, typically found in affirmative contexts. On the other hand, we have parar de + INF used in negative contexts to signal the absence of the interruption of the event expressed by the infinitive, giving rise to other nuances of meaning associated with the idea of insistence, repetition, or continuity of an action.

\begin{tabular}{|ll|}
\hline FORM & MEANING \\
[affirmative [parar de] [INF] & interruptive \\
[negative [parar de] [INF]] & repetition, insistence, continuation \\
\hline
\end{tabular}

Figure 2. Constructions associated with parar de + INF.

There are thus two different constructions associated with parar de + INF, as this verbal periphrasis cannot be understood without looking if it is preceded by a term of negative or positive polarity. ${ }^{5}$ Depending on whether the positive or negative term is used, parar de + INF will take on one meaning or another. This is a characteristic that it shares with other aspectual verbal periphrases. In general, as we shall see, negated meanings may adopt modal values supplementing those related to aspect.

\subsection{Parar de + INF As an Interruptive Verbal Periphrasis}

As we have explained thus far, in affirmative constructions, parar de + INF expresses the interruption of an event. In this usage, it is observed that, as Aparicio Mera (2016) argues, with the verb parar, a larger amount of energy is required in order to stop the event described by the infinitive than that required by dejar de + INF. Thus, in a statement such as the one seen in (14), the effect is stronger if the utterance is formulated using parar instead of dejar, a verb permitting greater attenuation in the formulation of orders. The exclamation contained in (14) instructs the receivers of the message to stop talking. The limiting phrase "gritó con su voz de pajarraco" ('yelled with his ugly bird voice') confirms that the order expressed with a clear perlocutionary intent (the quieting down of the people who are arguing) is not a polite one.

(14) - ¡Ya paren de discutir que son casi las ocho! — gritó con su voz de pajarraco. (Isaac Goldemberg, El nombre del padre, Perú, 2001, corpes xxi)

"'Stop arguing now, it's almost eight!" He yelled with his ugly bird voice.'

Following the description in terms of force dynamics proposed by Aparicio Mera (2016), the choice of parar de + INF is often related to the expression of a greater force or impulse, lending a more emphatic sense to the statements containing parar de + INF when compared to those that use dejar de + INF. The verb dejar, as a lexical verb, simply refers to the idea of 'leaving something in a particular place', whereas parar involves the interruption of a motion, and this means the subject must exert more control or force to stop the movement in progress. This notion of greater control would persist (in the sense put forth by Hopper 1991) in the verbal periphrasis, such that the difference between paren de discutir ('stop arguing') and dejen de discutir ('stop arguing') lies in the idea of insistence being attributed to the verbal form using parar, in contrast to the more neutral dejen de discutir.

Therefore, in instructions where one seeks a certain perlocutive effect in the receiver, the choice of parar de + INF in the affirmative will be more forceful than its counterpart with the verb dejar. This is seen in the order contained in (14) or in the indirect order in (15). 
(15) Estoy seguro de que Isabel se encontró con él para decirle que pare de molestar. (Marcelo

Birmajer, Historia de una mujer, Argentina, 2007, corpes xxi)

'I am sure that Isabel met with him to tell him to stop bothering her.'

Significantly, if we look at the type of verbs which, in the twenty-first century, tend to function as the auxiliated verbs in this construction, the events they refer to very often tend to represent actions which can be annoying. The verbs that appear most frequently in this verbal periphrasis are usually hablar or llorar ('talk' or 'cry'). These have frequencies of 9.1 and 6.1 per million words, respectively (cf. Section 4.3).

Outside the deontic context, the verbal periphrasis parar de + INF expresses an abrupt interruption of the event expressed by the infinitive, which may or may not be resumed later on. This is the case of (16), where the action of cortar ('cutting') is abruptly suspended.

(16) En la cocina, Leocadia paró de cortar. (Cristina Sánchez-Andrade, Bueyes y rosas dormían, España, 2001, corpes xxi)

'In the kitchen, Leocadia stopped cutting.'

Indeed, contrary to Camus Bergareche (2006, p. 207), the construction parar de + INF does not seem to express the interruption of events that will not "be resumed". An example of this can be found in (17), where the verbal periphrasis is accompanied by the time expression un momento ('one moment'), which indicates that the person has only stopped studying for a moment. Furthermore, in example (18a), we observe that it is precisely as a consequence of the use of dejar de + INF in the verbal periphrasis that one can infer that the event expressed by the infinitive is less likely to be resumed. Dejar de hablar a alguien ('stop talking to someone') gives rise to the inference that the interlocutor is no longer speaking to that person and that this is permanent or definitive. Conversely, parar de hablar ('stop talking'), when directed to a person, is a pragmatically odd statement (18b). This is not the case, however, if one wants to refer to the action of talking being interrupted (18c). Elsewhere, the difference between dejar de hablar ('stop talking') and parar de hablar ('stop talking') sometimes conveys a certain sense of relief on the part of the speaker if the construction containing parar is used (cf. 18d and 18e).

(17) Ibai

@IbaiLlanos

Si tenéis que estudiar por qué cojones estáis en Twitter podéis ser responsables por favor.

'If you have to study then why the hell are you on Twitter can you be responsible please.

\section{Antoniojrg}

@erbarto16

Justo lo primero que veo cuando he parado un momento de estudiar, sienta como una patada en el pecho. (Twitter, 25 May 2018)

'the very first thing I see when I stop studying for a moment, feels like a kick to the chest.'

(18) a. Dejó de hablarme en cuanto supo que yo no le iba a votar. 'He stopped speaking to me when he found out I wasn't going to vote for him.' b. ?Paró de hablarme en cuanto supo que yo no le iba a votar. 'He stopped talking to me when he knew I wasn't going to vote for him.' c. Solo paró de hablar cuando se lo supliqué. 'He only stopped talking when I begged him [to stop].' d. Dejó de hablar cuando acabó su charla. 'He/she stopped speaking when he/she ended his/her talk.' e. Paró de hablar cuando acabó su charla. 'He/she stopped talking when he/she ended his/her talk.'

At any rate, the interruption expressed by parar de + INF may also manifest something that is somewhat definitive:

(19) MaRiA cAnDeL

@mariacandel05 
Quiero parar de ser dislexica (sic) dios dios dioss aaaaa. (Twitter, 23 April 2021)

'I want to stop being dyslexic god god godddd aaaaaa.'

These examples seem to make it clear that, rather than the verbal periphrasis, it is the context which allows us to infer whether the interruption is momentary or definitive. For instance, in contrast to the previous examples, in (20) the sense of parar de + INF is close to that of acabar de + INF (finish doing something), showing some neutralisation between the finalising and interruptive verbal periphrases. Even so, the difference has to do with the fact that the verb parar does not suggest that the conversation has come to an end.

(20) Durante 73 segundos el mundo tuvo que esperar que Obdulio parara de hablar con dos británicos en su castellano estragado en suburbios montevideanos y devolviera el balón. (Jorge Valdano, El miedo escénico y otras hiervas, Argentina, 2002, corpes xxi)

'For $73 \mathrm{~s}$ the world had to wait for Obdulio to stop talking to two Britons in the Spanish spoiled in the suburbs of Montevideo and return the ball.'

Studies of parar de + INF describe this verbal periphrasis as a construction that is especially associated with interpretations implying the subject's lack of control over the verbal event (Camus Bergareche 2006, p. 208). Indeed, this is one of the contexts where this form may appear. Accordingly, in (21), former Spanish president Aznar no longer appears on television, yet this is not the result of the speaker's personal decision, in contrast to the volitional nature of the statement in (18a).

(21) Yo creo que Aznar ya va/ / ya va a parar de salir en la tele y en todas esas partes/ahora/ nos va/eeh vamos a ver mucho a Rajoy. (Corales, La ventana: la tertulia de los niños, 30.October.2003, Cadena Ser, corpes xxi)

'I think that Aznar is now / / now he's going to stop appearing on the tele and everywhere/now / he is/eh we're going to see Rajoy a lot.'

Now, the utterances in which the subject of parar de + INF has no control over the event expressed by the infinitive are not the only uses of this verbal periphrasis. The etymological meaning of dejar ('leave something somewhere') implies a conscious decision on the part of the subject, which can be seen in examples such as (18a) or (22b). This conscious decision is in keeping with the forceful control on the part of the subject. In contrast, in parar ('stop a movement'), the action of stopping may be caused by a fortuitous occurrence or the result of a voluntary decision. Thus, in (22), abandoning one's studies presents itself either as a result of prior deliberation (22b), or as a pause in one's studies that does not necessarily imply a conscientious decision to do so (22a). Even so, this is not enough of a reason to ignore that parar de + INF can be used with subjects who have control over the verbal action. What is more, there is as much control in Dejó de estudiar ('he abandoned his studies') as there is in Paró de estudiar ('he stopped studying'). The difference stems from the fact that in the verbal periphrasis using parar, the interruption is momentary: someone has suspended her/his studies to work; in contrast, in the form containing dejar, what is conveyed is that they are abandoning their studies for good.

(22) a. Paró de estudiar para ponerse a trabajar.

'He stopped studying to work.'

b. Dejó de estudiar para ponerse a trabajar.

'He abandoned studying to work.'

However, a more in-depth investigation of these aspects is needed, as the form parar $d e+$ INF found in Spanish-American texts appears in contexts for which the interruption of the activity may be definitive, as in (23a), where the meaning referring to the interruption of one's studies is near to that denoted in dejar de + INF, or in (23b), where the person is contemplating quitting smoking for good. Nevertheless, these characteristics shared with the verbal periphrasis dejar de + INF are also seen, albeit to a lesser degree, in Spain (cf. 24) and may be indicative of a further step in the process of the constructionalisation of the verbal periphrasis parar de + INF. 
(23) a. Tengo que pensar en todo eso. Tengo muchas dudas. Tal vez pare de estudiar. (Rodrigo Rey Rosa, Carta de un ateo guatemalteco al Santo Padre, Guatemala, 2020, corpes xxi)

'I have to think about all of this. I have a lot of doubts. Perhaps I will stop studying.' b. Si para de fumar, sin duda tendrá un olor más agradable y un aliento más fresco. También tendrá un aspecto más juvenil.' ...

(Guatemala, "Signos Vitales Asociación”. Available online: https:/ / www.localgymsandfitness. com/GT/Guatemala-City/441040315932990/Signos-Vitales-Asociación (accessed on 8 May 2021)

'If you stop smoking, you will without any doubt smell better and have fresher breath. You will also look younger.'

(24) El riesgo de desarrollar un cáncer siempre disminuye si se para de fumar, dice Jorge García. (La voz de Galicia 17.04.2016. Available online: https: / / www.lavozdegalicia.es/noticia/ extravozok/2016/04/17/esperas-dejar-tabaco/0003_201604SO17P2991.htm (accessed on 8 May 2021)) 'The risk of developing cancer always decreases if you stop smoking.'

We believe that the assertion that parar de + INF is exclusively associated with contexts in which the subject has no control over the event may be due, in part, to the fact that the verbal periphrasis usually appears with verbs of emotion, such as reir ('to laugh') or llorar ('to cry'), in passages where these emotions fall out of the control of the subject, very often inserted in periphrastic chains along with the verb poder ('can/be able to') preceded by negation (25). Furthermore, the lexical meaning of parar ('to stop') refers to an event that can happen as a result of a fortuitous situation.

(25) No podía parar de reír.

'He/she couldn't stop laughing.'

Although we shall revisit these structures in Section 4.2, it is worth bearing in mind that, elsewhere, the interruption of any event requires control on the part of the subject, and parar de + INF can also be combined with volitive constructions, such as that seen in (26), where the speaker asks an interlocutor to stop crying.

(26) ¿Quieres parar de llorar?

'Do you want to stop crying?'

In fact, if we consider the greater emphatic character of parar de + INF, where the subject would require a higher amount of energy to interrupt an event with respect to that needed when using dejar de + INF, it is not impossible that the control over the act of interrupting the event contained in the infinitive is greater with parar than with dejar. Another matter is that with dejar de + INF, the action is interrupted after some deliberation on behalf of the subject, as this act of deliberation is normally absent in the construction with parar de + INF. In addition, some of the constructions which the relevant literature considers to be pragmatically anomalous, and which were cited as examples showing that parar de + INF does not function in constructions with agentive subjects, have been found in the corpora. This is the case of parar de fumar or parar de beber ('stop smoking' or 'stop drinking'), found on various occasions on Twitter and in literary texts, in contrast to Camus Bergareche (2006, p. 208):

(27) a. ¿Algún día pararás de fumar? (Si es que fumas). (Twitter, 7 April 2015)

'One day will you stop smoking? (If you do smoke).'

b. Pero a partir de ese día el Fata había parado de beber y Eleuterio sentía que en esa fecha ambos habían dejado de ser adolescentes. (Eduardo Labarca, Cadáver tuerto, 2005, Chile, corpes xxi)

'But after that day Fata had stopped drinking and Eleuterio felt that on that day both had stopped being adolescents.'

Yet we cannot ignore the fact that this construction often appears in imperative contexts as well; it is in these contexts where the speaker orders the receiver to stop the 
action under the receiver's control, such as talking, or other actions that may annoy people on the receiving end (cf. 14-15 above).

In summary, in affirmative contexts, parar de + INF expresses the categorical interruption of an event expressed by the infinitive, revealing the etymological meaning of the verb parar. Furthermore, the verbal periphrasis is largely documented with animate subjects who are able to control the verbal event (as opposed to what is maintained by Camus Bergareche 2006, p. 208), as shown in Figure 3. On top of that, the construction has changed over time to enable its use with inanimate subjects (28) and even zero subjects (29).

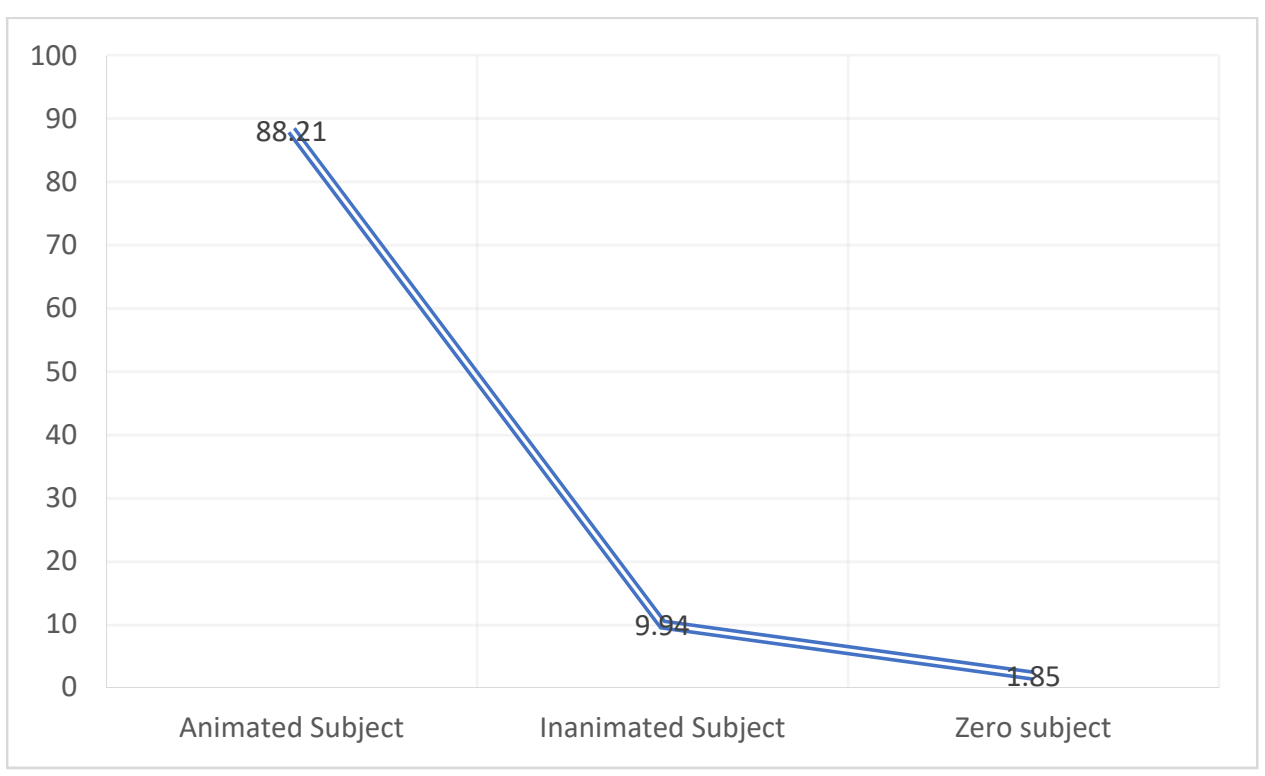

Figure 3. Percentage of use of parar de + INF with animate, inanimate, and zero subjects.

(28) Ilan sonríe y se va. Los soldados le esperan. Las plumas paran de caer. (Aurora Mateos, El suicidio del ángel, España, 2006, corpes xxi)

'Ilan smiles and leaves. The soldiers wait. The feathers stop falling.'

(29) Te prestaría algo, no voy a mojar mis prendas porque sí, espera a que pare de llover. (Isaura Contreras, La casa al fin de los días, México 2007, corpes xxi)

'I would lend you something, I'm not going to get my clothes wet just because, wait for it to stop raining.'

\subsection{Parar de + INF As a Verbal Periphrasis Expressing Repetition or Continuity}

As indicated above, the most prototypical use of parar de + INF is seen in negative contexts where the notion of interruption is cancelled. Thus, parar de + INF comes to express the idea of an iterated repetition of the action expressed by the infinitive or the absence of interruption (30). As opposed to what is cited in the literature on this topic, which usually identifies the negation of parar de + INF with the verbal periphrasis of seguir + GER ('continue' + GER), the NEG. parar de + INF construction does not express gradual uninterrupted continuity starting sometime in the past in every context of use. Looking at (30), the reformulation of these utterances does not lead us to interpret them as Sigo pensando en esto ('I continue thinking about this') or Seguía pensando en sus labios ('I continued thinking about her lips') but as He pensado una y otra vez, he estado pensando todo el tiempo, Recordaba sin pausa sus labios ('I have thought over and over again, I have been thinking about this non-stop, I ceaselessly recalled her lips').

(30) a. Llevo todo el día sin parar de pensar en esto. (Twitter, 22 April 2021)

'All day long I have not stopped thinking about this.'

b. @NicolasLemes 
Él no paraba un momento de recordar sus labios. (Twitter, 28 December 2016)

'He did not stop for one moment recalling her lips.'

More examples are found in (31) and (32). In (31) the action of hablar (speaking) is described as something that happens habitually. In (32), the telic nature of tener accidentes ('having accidents') favours the idea of repetition, as opposed to the sense of continuity expressed by seguir + GER.

(31) Ya cállate, Mica. Nomás despiertas y no paras de hablar. (Silvia Peláez, Acorazados, México, 2008, corpes xxi)

'Shut up, Mica. You wake up and don't stop talking.'

(32) Yo es que tengo la negra. No paro de tener accidentes. (Francisco Nieva, El Cíclope, España, 2009, corpes xxi)

'I have the black [a jinx]. I don't stop having accidents.'

In other words, the NEG. parar de + INF construction should not be univocally identified with the verbal periphrasis seguir de + INF ('continue' + INF). In many instances, the construction NEG. parar de + INF does not mean that an action occurring prior to the utterance continues once it is uttered, but that the action is repeated over and over again for a specific period of time. In other words, as opposed to seguir + GER ('continue' + GER), the NEG. parar de + INF construction is not anchored to a moment prior to the utterance; it does not involve a prior phase in which the action denoted by the infinitive has occurred. If parar de + INF expresses continuity, it is because the context of use (or the aktionsart) of the auxiliated verb itself activates the inference of continuity of the action expressed by the infinitive starting at a time in the past. This is the mechanism at play in (33), where the action of escribir ('writing') is interpreted as being uninterrupted and, therefore, continuing into the present time. This is also observed in (34), where the presence of the time complement desde que fue cercada en otoño ('since coming under siege in the autumn') means that the action expressed by parar is interpreted as having started in the past and as being still in progress. The meaning adjacent to seguir + GER is also activated when a time complement is also used that places a future limit on the action, as with hasta que llegamos ('until we arrived') in (35).

(33) No sabemos nada. Y sin embargo no paramos de escribir. (Miguel Ángel Hernández, No (ha) lugar, España, 2007, CORPES XXI)

'We don't know anything. And still, we do not stop writing.'

(34) Pero los habitantes de Leningrado no han parado de sufrir esa situación desde que fue cercada en otoño. (Jorge M. Reverte, La división azul. Rusia 1941-1944, España, 2011, corpes xxi)

'Yet the inhabitants of Leningrad have not stopped suffering from this situation since coming under siege in autumn.'

(35) ( . . ) no paramos de correr hasta que llegamos a Postrer Valle. (Juan Ignacio Siles del Valle, Los últimos días del Che, Bolivia, 2007, corpes xxi)

' ( . . . ) we did not stop running until we arrived at Postrer Valle.'

Therefore, NEG. parar de + INF expresses continuative meanings that can be presented as an accumulative or intermittent action. As such, the question arises as to why, in Spanish, there is a tendency to coin continuative constructions using negative modal verbal constructions that include phase verbs which express interruption. If, in these contexts, these negative modal verbal periphrases really acted as synonyms of seguir + GER ('continue' + GER) it is difficult to understand why an interruptive phase verb is used to express the continuity of an event. Conversely, in negating the verbal periphrasis, we are able to express an action that is prolonged and intensive (and at times repetitive) over time, and therefore the choice of an interruptive construction is logical. That is, when parar de + INF is negated, not only is the speaker negating the interruption of the event denoted by the infinitive, but they are also conveying the idea that this continued action is excessive or repeating ceaselessly. This same idea is formulated in Aparicio Mera (2016, 
p. 291), for whom the sentence Beatriz no paraba de llorar en la cama mientras él se cepillaba los dientes ('Beatriz did not stop crying in bed while she brushed her teeth') not only means "Beatriz continues to cry" but that "she is crying a lot". Not only this, but, in our opinion, the emphatic sense of the utterance proposed by Aparicio Mera (2016) is more marked than in seguir + GER ('continue' + GER), which is a more neutral expression. In effect, the negative readings of parar de + INF tend to be accompanied by a modal sense which relates to annoyance or anger on behalf of the speaker. For instance, in (37), the laughter of the interlocutor makes the speaker angry, who adds the additive marker encima ('on top of that'), which often appears in contexts containing pieces of information whose line of argument carries an unfavourable connotation (Garachana 2008).

(36) Contigo nada es serio, nena. ¿No ves que casi causas un desastre? Y encima no paras de reírte. (Amaya Ascuncé, En la cocina con la drama mamá. El libro de recetas que no conseguí escribir, España, 2013, corpes xxi)

'With you nothing is serious, girl. Can't you see that you nearly caused a disaster? And on top of that you won't stop laughing.'

There are instances, however, where only the idea of insistence or the overly frequent nature of the event designated by the infinitive is added, as in (37). Here, the success of the Greenfluencers initiative is expressed by way of the verbal periphrasis no paramos de recibir mensajes ('we don't stop receiving messages'). This also occurs in (38), with no pararon de aplaudir ('they did not stop applauding'), or in (39), with no ha parado de dar alegrías ('[He] has not stopped making us happy'). This idea of elevated repetition, often coinciding with the idea that the event is taking place in a manner running counter to one's expectations, is frequently seen in formal texts.

(37) Los mensajes privados de Greenfluencers están "colapsados", según Burque. "No paramos de recibir mensajes de gente que nos pide consejos para cuidar sus plantas". (Emilio Sánchez Hidalgo, Verne. El país, España 2019, corpes xxi)

"The private messages of Greenfluencers have "collapsed", according to Burque. "We keep receiving messages from people asking us for advice on how to take care of their plants".'

(38) Tras observar el vídeo, los reporteros, que nos visitan en esta ocasión de Miss Universo, no pararon de aplaudir, pues quedaron fascinados con la riqueza de esta nación. (La hora, 2004, Ecuador, corpes xxi)

'After watching the video, reporters, who are visiting us on the occasion of Miss Universe, do not stop applauding, as they were fascinated by the wealth of this nation.'

(39) Al año siguiente, el entonces presidente azulgrana Joan Laporta le entregó las riendas del primer equipo y, desde los dos primeros sustos en la Liga, Guardiola no ha parado de dar alegrías a los barcelonistas tras acumular victorias y títulos. (Anonymous, Sport.es, España, 2010, corpes xxi)

'The following year, the then president of Barça F.C. Joan Laporta gave him the reins of the first team, and, after the first two scares in La Liga, Guardiola has not stopped making Barcelona fans happy after accumulating wins and titles.'

Therefore, the twentieth and twenty-first centuries have witnessed, in the Spanish verbal periphrases system, the emergence of a continuative construction from an interruptive structure specialised in expressing repetition and a variety of modal senses connected to emphasis, excess, and annoyance. Perhaps it is this emphatic sense which makes it suitable for use in periphrastic chains, normally in negative structures (cf. Table 2), headed by the modal verbs poder ('can'), deber ('must'), and querer ('want'). 
Table 2. Periphrastic chains containing parar de + INF.

\begin{tabular}{|c|c|c|c|c|c|c|c|c|c|}
\hline Polarity & $\begin{array}{l}\text { DEBER } \\
\text { 'must' }\end{array}$ & $\begin{array}{c}\text { Hacer } \\
\left({ }^{\prime} \mathrm{do}^{\prime}\right) \text { Causative } \\
\text { Value }\end{array}$ & $\begin{array}{c}\text { Hay Que } \\
\text { ('need } \\
\text { to/must') }\end{array}$ & $\begin{array}{c}\text { Ir a } \\
(\text { ('go') }\end{array}$ & ('Manage') & $\begin{array}{l}\text { Poder } \\
\text { ('can') }\end{array}$ & $\begin{array}{l}\text { QUERER } \\
\text { ('want') }\end{array}$ & $\begin{array}{c}\text { Saber } \\
\left({ }^{\prime} \text { know') }^{\prime}\right)\end{array}$ & $\begin{array}{l}\text { Tener Que } \\
\text { ('have to') }\end{array}$ \\
\hline Positive & 6 & 1 & & 1 & & 8 & 1 & & 4 \\
\hline Negative & 3 & & 1 & 8 & 1 & 103 & 5 & 1 & \\
\hline Total & 9 & 1 & 1 & 7 & 1 & 109 & 5 & 1 & 4 \\
\hline
\end{tabular}

These structures are used to express the (in)capacity of the subject of the verbal periphrasis to stop themselves from carrying out an action out of their control (40), orders formulated in the interrogative (41), the obligation to stop a repeated action (or not) (42), or the wish to continue or interrupt a given behaviour (43)-(44).

(40) a. No podía parar de pensar y de desearle lo peor. (Alejandro López, La asesina de Lady Di, Argentina, 2001, corpes xx)

'He/she could not stop thinking and wishing the worst for him/her.'

b. ( . . ) no podían parar de reírse aunque los ojos se les llenaran de lágrimas. (Liliana Heker, La crueldad de la vida, Argentina, 2001, corpes xx)

'( . . . ) they could not stop laughing although their eyes filled with tears.'

(41) SIRENA. ¿Podés parar de mover los brazos?... ¡Me mareás! (Liliana Heker, La crueldad de la vida, Argentina, 2001, corpes xx)

'SIRENA: Could you stop moving your arms? You're making me dizzy!'

(42) Debemos parar de darnos palmaditas cuando esporádicamente alguno de nuestros deportistas tenga una buena figuración. (Alejandro Bermúdez, El tiempo, Colombia, 2009, corpes xxi)

'We must stop giving ourselves a pat on the back when one of us athletes sporadically performs well.'

(43) Dice Calamaro: ¿Es razonable querer parar de hacer el amor? (Toni Segarra, Desde el otro lado del escaparate, España, 2009)

'Calamaro says: Is it reasonable to want to stop making love?'

(44) No quiero parar de estudiar. (Sarai Cabral, El universal, México, 2011, corpes xxi)

'I don't want to stop studying.'

\subsection{Verbal Forms Associated with the Infinitive in Parar de + INF Constructions}

The meaning of parar de + INF is suited for situations susceptible to being interrupted. Therefore, the verbs that appear in the infinitive verb position are largely verbs expressing actions that are dynamic, durative, and atelic, as indicated by Olbertz (1998). As a result, permanent states and accomplishments can only be used with this construction when they take on senses associated with habitual or iterative events, such as in (45)-(49). When the construction is otherwise used with permanent states (50) or achievements (51) it is pragmatically anomalous.

(45) Para de ser tan pesado, niño.

'Stop being such a pest, boy.'

(46) Para de estar nervioso.

'Stop being nervous.'

(47) Se para de vivir cuando se para de leer. (https:/ / www.diariodenavarra.es/participacion/ cartasaldirector/contenidos/se-para-vivir-cuando-para-leer-8085-109.html (accessed on 8 May 2021))

'One stops living when they stop reading.'

(48) No puedo parar de ser yo misma.

'I can't stop being myself.' 
(49) No puedo parar de entrar y salir.

'I can't stop entering and leaving.'

(50) ?A ver cuándo paras de vivir con tu madre.

'Let's see when you stop living with your mother.'

(51) ?No para de morir.

'He/she can't stop dying.'

If we look at Table 3 with the verbal forms from our corpus appearing in the infinitive verb position more than ten times, we observe that most of the verbs express activities and accomplishments. In our corpus, the stative verbs and achievements represent the minority.

Table 3. Verbs appearing in the infinitive position in the construction parar de + INF.

\begin{tabular}{|c|c|c|c|}
\hline Verb & Absolute Frequency & Frequency per Million Words & Aktionsart \\
\hline hablar ('to talk') & 361 & 9.1 & activity \\
\hline llorar ('to cry') & 244 & 6.15 & activity \\
\hline reír ('to laugh') & 234 & 5.89 & activity \\
\hline hacer ('to do') & 138 & 3.47 & activity \\
\hline $\begin{array}{l}\text { dar (giros que significan molestar) } \\
\text { ('to turn out, creating an annoyance') }\end{array}$ & 125 & 3.15 & activity \\
\hline crecer ('to grow') & 113 & 2.84 & activity \\
\hline llover ('to rain') & 93 & 2.34 & activity \\
\hline mover ('to move') & 85 & 2.14 & activity \\
\hline mirar ('to look') & 77 & 1.94 & activity \\
\hline trabajar ('to work') & 71 & 1.78 & activity \\
\hline sonar ('to ring') & 67 & 1.68 & activity \\
\hline decir ('to say') & 65 & 1.63 & activity \\
\hline gritar ('to yell') & 56 & 1.41 & activity \\
\hline comer ('to eat') & 56 & 1.41 & activity/accomplishment \\
\hline pensar ('to think') & 54 & 1.36 & activity \\
\hline correr ('to run') & 50 & 1.26 & activity \\
\hline preguntar ('to ask') & 47 & 1.18 & accomplisment \\
\hline $\begin{array}{c}\text { tocar (instrumentos) ('to play an } \\
\text { instrument') }\end{array}$ & 40 & 1 & activity \\
\hline bailar ('to dance') & 41 & 1 & activity \\
\hline repetir ('to repeat') & 36 & 0.9 & activity \\
\hline sonreír ('to smile') & 34 & 0.85 & activity \\
\hline beber ('to drink') & 32 & 0.8 & accomplishment \\
\hline escribir ('to write') & 32 & 0.8 & accomplishment \\
\hline llamar ('to call') & 30 & 0.75 & activity \\
\hline llegar ('to arrive') & 26 & 0.65 & accomplishment \\
\hline leer ('to read') & 24 & 0.6 & accomplishment \\
\hline toser ('to cough') & 22 & 0.554575 & repeated achievement \\
\hline $\begin{array}{l}\text { tomar (beber, tomar fotos, tomar el } \\
\text { pelo) ('to drink', 'to take photos', 'to } \\
\text { pull someone's leg') }\end{array}$ & 21 & 0.529367 & activity \\
\hline
\end{tabular}


Table 3. Cont.

\begin{tabular}{|c|c|c|c|}
\hline Verb & Absolute Frequency & Frequency per Million Words & Aktionsart \\
\hline fumar ('to smoke') & 21 & 0.52 & activity \\
\hline quejarse ('to complain') & 20 & 0.504159 & activity \\
\hline subir ('to go up') & 20 & 0.504159 & accomplishment \\
\hline temblar ('to tremble') & 19 & 0.478951 & activity \\
\hline jugar ('to play') & 19 & 0.47 & activity \\
\hline recibir ('to receive') & 18 & 0.453743 & achievement \\
\hline salir ('to go out') & 18 & 0.453743 & achievement \\
\hline entrar ('to come in') & 18 & 0.45 & achievement \\
\hline besar ('to kiss') & 16 & 0.403327 & activity \\
\hline buscar ('to look for') & 16 & 0.403327 & activity \\
\hline aumentar ('to increase') & 16 & 0.4 & activity \\
\hline discutir ('to argue') & 16 & 0.4 & activity \\
\hline saltar ('to jump') & 15 & 0.378119 & achievement \\
\hline meter ('to put') & 15 & 0.378119 & achievement \\
\hline cantar ('to sing') & 14 & 0.35 & activity \\
\hline remover ('to stir') & 13 & 0.327704 & activity \\
\hline sangrar ('to bleed') & 13 & 0.327704 & activity \\
\hline viajar ('to travel') & 13 & 0.327704 & activity \\
\hline ladrar ('to bark') & 13 & 0.327704 & activity \\
\hline caer ('to fall') & 13 & 0.32 & achievement \\
\hline sufrir ('to suffer') & 12 & 0.302496 & state \\
\hline imaginar ('to imagine') & 12 & 0.302496 & activity \\
\hline lanzar ('to throw') & 12 & 0.302496 & achievement \\
\hline pedir ('to ask for something') & 12 & 0.302496 & achievement \\
\hline sacar ('to remove') & 12 & 0.302496 & achievement \\
\hline recordar ('to remember') & 11 & 0.277288 & state/achievement \\
\hline ver ('to see') & 11 & 0.277288 & state \\
\hline rascarse ('to scratch oneself') & 10 & 0.25208 & activity \\
\hline rezar ('to pray') & 10 & 0.25208 & activity \\
\hline vomitar ('to vomit') & 10 & 0.25208 & activity \\
\hline $\begin{array}{l}\text { saludar ('to greet/to wave to } \\
\text { someone') }\end{array}$ & 10 & 0.25208 & activity \\
\hline girar ('to turn') & 10 & 0.25 & activity \\
\hline
\end{tabular}

\section{Conclusions}

This study focused on two Spanish verbal periphrases which appear mainly in the twenty-first century. Despite existing since the Middle Ages, they were scarcely used before the contemporary era, and it is only at this point when we begin to observe a significant increase in their frequency of use. Parar de + INF is a verbal construction articulated in two micro-constructions, each having its own well-differentiated meaning and structure, namely, AFFIRM. parar de + INF and NEG. parar de + INF.

The first construction (AFFIRM. parar de + INF) expresses an interruptive meaning, in other words, parar de + INF avoids the culmination of the event expressed by the infinitive. 
Interruptive structures very often formulate orders directed to an interlocutor to detain an action the speaker finds annoying (parar de gritar; 'stop yelling'). On other occasions, parar $d e+$ INF is used to indicate that the event expressed by the infinitive has been interrupted for various reasons. When AFFIRM. parar de + INF is used, it means that the event expressed by the infinitive has been interrupted, but whether or not the action will resume is left open. Thus, the difference between Ha dejado de hablar ('She/he stopped talking') and Ha parado de hablar lies in the fact that dejar de hablar ('to stop talking') implies that the talking shall not resume, whereas in ha parado de hablar the possibility exists that he/she may resume talking.

The second construction (NEG. parar de + INF) is much more frequent in all Spanishspeaking countries. When parar de + INF is negated, a verb of aspect which expresses the interruption of an action is used in order to convey a sense of continuity. That is, instead of using a verb denoting the continuation of an action, another construction is chosen whose sense combines negation with interruption. Expressions of this type, based on indirect formulation, often give rise to diverse modal values. Thus, NEG. parar de + INF has specialised in indicating an action not expected by the speaker or that continues over time to a degree that they feel is excessive or bothersome (no para de quejarse; 'he/she does not stop complaining').

Parar de + INF, in both its affirmative and negative uses, is characterised by its marked oral character, which does not prevent it from appearing in formal texts, although these are not the usual contexts in which it is found. Indeed, although the corpora available to us largely consist of written texts, the passages in which parar de + INF appears refer to situations marked by communicative proximity. Therefore, it can be stated that AFFIRM. parar de + INF and NEG. parar de + INF are two verbal periphrases that are particularly associated with discourse traditions whose communicative situations feature a marked proximity between interlocutors.

Funding: This work was funded by the projects Diccionario histórico de las perífrasis verbales del español. Gramática, pragmática y discurso (III). Perífrasis formadas a partir de verbos superléxicos y de movimiento of MINECO (PID2019-105415RB-I00) and Gradia. Grup de Gramàtica i Diacronia (2014 SGR 994) of AGAUR.

Institutional Review Board Statement: Not applicable.

Informed Consent Statement: Not applicable.

Data Availability Statement: Not applicable.

Conflicts of Interest: The author declares no conflict of interest.

\section{Notes}

Suplemento is used in some Spanish functional grammar approaches to refer to adverbial complements.

2 The concept of force dynamics was coined by Talmy $(1988,2000)$. According to this author, the experience of humans in their environment can be applied to language and cognition. Thus, the physical experience of forces that are required in order to cause a particular action can be mapped onto the cognitive plane and used to express different concepts. The force dynamics model involves some participants (those who exert forces and others in charge of containing it), tendencies in terms of force (referring to movement or rest) and the equilibrium of forces (the entity exerting the greatest force tips the balance in its favour), and a resulting interaction of forces (which is translated into movement or keeping the entity at rest and means that some entities are successful and others fail). In the case of the verbal periphrasis parar de + INF in its interruptive sense, the subject of the predicate exerts a force in order to detain the event expressed by the infinitive. This force uses energy.

3 We use the concept of communicative proximity in keeping with the theoretical considerations of Koch and Oesterreicher (1990/2007), who opt for a characterisation of communicative situations in terms of a continuum ranging from genres typically associated with communicative proximity or immediacy (e.g., a colloquial conversation) to others where greater communicative distance prevails (e.g., legal texts).

4 Our use of the concept of grammatical construction is the same as that used in the field of construction grammar. Here, a grammatical construction is a conventionalised pattern that relates a form with a particular meaning. Constructions are much more than a combination of words: a construction is a clause or syntactic phrase just like a word or morpheme. Furthermore, constructions are formulated at different levels of abstraction. Thus, there are constructions that are maximally saturated, such as Salomé hizo matar a Juan ('Salome had Juan killed'), and others that are maximally schematic (e.g., causative constructions (X verb 
$Y Z^{\prime} X$ makes $Y$ do $\left.Z^{\prime}\right)$ ). Between the schematic causative construction and the one explicitly formulated with words, one can find others that are more or less saturated, such as ' $X$ had $Y$ killed' or ' $X$ made $Y$ INF'. For more information, see Goldberg (1995) and Goldberg and Casenhiser (2006), and for Spanish, see Gras Manzano (2011) and Garachana (2021).

\section{References}

Aparicio Mera, Juan. 2016. Representación computacional de las perífrasis de fase: De la cognición a la computación. Barcelona: Universidad de Barcelona.

Bravo Martín, Ana, and Luis García Fernández. 2016. Perífrasis verbales. In Enciclopedia lingüística hispánica, vol. I. Edited by Javier Gutiérrez-Rexach. Londres: Routledge, pp. 785-96.

Camus Bergareche, Mario. 2006. Parar de + infinitivo. In Diccionario de perífrasis verbales. Edited by Luis García Fernández. Madrid: Gredos, pp. 206-9.

Cornillie, Bert, Giulia Mazzola, and Miriam Thegel. 2021. Las Tradiciones Discursivas en tiempos de lingüística cuantitativa: ¿corrección epistemológica o deconstrucción metodológica? Leuven: K.U. Leuven.

Fernández de Castro, Félix. 1999. Las perífrasis verbales en el español actual. Madrid: Gredos.

Garachana, Mar. n.d. Evolución de las verbales interruptivas en español. Dejar de + INF, Parar de + INF y Cesar de + INF. In Construcciones Verbales Aspectuales. Precedentes Latinos y diacronía en español de las Construcciones Fasales. Beihefte zur Zeitschrift für romanische Philologie. Berlin: De Gruyter.

Garachana, Mar. 2008. En los límites de la gramaticalización. La evolución de encima (de que) como marcador del discurso. Revista de Filología Española 88: 7-36. [CrossRef]

Garachana, Mar. 2021. Gramática de construcciones. In Sintaxis del español/The Routledge Handbook of Spanish Syntax. Edited by Guillermo Rojo, María Victoria Vázquez and Rena Torres. London: Routledge.

García, Erica. 1967. Auxiliaries and the criterion of simplicity. Language 43: 853-70. [CrossRef]

García Fernández, L. 2006. Diccioinario de perifrasis verbales. Madrid: Gredos.

Goldberg, Adele. 1995. Constructions: A Construction Grammar Approach to Argument Structure. Chicago: Chicago University Press.

Goldberg, Adele, and Devin Casenhiser. 2006. English Constructions. In Handbook of English Linguistics. Londres: Blackwell Publishers, pp. 343-55.

Gómez Manzano, Pilar. 1992. Perífrasis verbales con infinitivo. Madrid: UNAM.

Gómez Torrego, Leonardo. 1988. Perífrasis verbales. Sintaxis, semántica y estilística. Madrid: Arco Libros.

Gómez Torrego, Leonardo. 1999. Los verbos auxiliares. Las perífrasis verbales de infinitivo. In Gramática Descriptiva de la Lengua Española. Edited by Ignacio Bosque and Violeta Demonte. Madrid: Espasa-Calpe, pp. 3323-89.

Gras Manzano, Pedro. 2011. Gramática de Construcciones en Interacción. Propuesta de un modelo y aplicación al análisis de estructuras independientes con marcas de subordinación en español. PhD. Barcelona: University of Barcelona.

Havu, Jukka. 2011. La evolución de la perífrasis del pasado reciente acabar de + infinitivo. In Estudios sobre perífrasis y aspecto. München: Peniope, pp. 158-79.

Hopper, Paul. 1991. On some Principles of Grammaticalization. In Approaches to Grammaticalization, Vol. 1. Edited by Elizabeth Closs Traugott and Bernd Heine. Amsterdam and Philadelphia: John Benjamins Pub Co, pp. 17-35.

Kabatek, Johannes. 2013. ¿Es posible una lingüística histórica basada en un corpus representativo? Iberoromania 77: 8-28. [CrossRef]

Koch, Peter, and Wulf Oesterreicher. 1990/2007. Lengua Hablada en la Romania: Español, francés, italiano, 2nd ed. de la versión española de Araceli López Serena. Madrid: Gredos.

Laca, Brenda. 2002. Spanish «aspectual» periphrases: Ordering constraints and the distinction between situation and viewpoint aspect. In From Words to Discourse: Trends in Spanish Semantics and Pragmatics. Edited by J. Gutiérrez-Rexach. Amsterdam-Oxford: Elsevier, pp. 61-93.

Morera, Marcial. 1991. Diccionario crítico de las perífrasis verbales del español. Fuerteventura: Servicio de Publicaciones del Cabildo Insular de Fuerteventura.

Real Academia Española and Asociación de Academias de la Lengua Español. 2009. Nueva Gramática de la Lengua Española. Madrid: Espasa.

Olbertz, Hella. 1998. Verbal Periphrases in a Functional Grammar of Spanish. Berlin and New York: De Gruyter.

Smith, Carlota. 1991. The Parameter of Aspect. Dordrech Boston-Londres: Kluwer.

Talmy, Leonard. 1988. Force dynamics in language and cognition. Cognitive Science 12: 49-110. [CrossRef]

Talmy, Leonard. 2000. Towards a Cognitive Semantics I: Concept Structuring Systems. Cambridge: MIT Press. 